\title{
PELATIHAN PENERAPAN METODE GASING DALAM OPERASI PENJUMLAHAN, PENGURANGAN, PERKALIAN DAN PEMBAGIAN
}

\author{
Nursakiah ${ }^{1^{*}}$ \\ Erni Ekafitria Bahar² \\ 1,2Universitas Muhammadiyah Makassar, Makassar, Indonesia \\ $\underline{\text { nursakiah@unismuh.ac.id }}^{\left.1^{*}\right)}$ \\ erniekafitria@unismuh.ac.id $\left.{ }^{2}\right)$
}

\author{
Kata Kunci: \\ [Matematika, Metode \\ Gasing]
}

\begin{abstract}
Abstrak: Kegiatan Pengabdian Masyarakat ini (PKM) bertujuan untuk memberikan pengetahuan kepada guru-guru tentang metode pembelajaran matematika dengan langkah-langkah yang dapat membuat peserta didik menguasai matematika secara gampang, asik dan menyenangkan. Kegiatan ini memperkenalkan metode gasing pada materi penjumlahan, pengurangan, perkalian dan pembagian. Metode yang digunakan yaitu (1) Metode observasi, dilakukan dengan melakukan wawancara terhadap guru kelas untuk mengumpulkan data tentang metode yang digunakan dalam mengajarakan matematika terutama pada materi penjumlahan, pengurangan, perkalian dan pembagian, (2) Metode ceramah dan demonstrasi dilakukan pada saat menyajikan materi metode gasing, (3) Metode pemberian angket dilakukan setelah penyampaian materi untuk mengetahui respon peserta pelatihan selama kegiatan pelatihan. Peserta kegiatan sebanyak 28 orang yang merupakan guru kelas pada Sekolah gugus V Wilayah III Kecamatan Herlang Bulukumba. Peserta pelatihan antusias selama kegiatan ini. Hasil pengabdian ini adalah: (1) peserta pelatihan memahami menghitung dengan metode gasing pada materi penjumahan, pengurangan, perkalian, dan pembagian; (2) peserta pelatihan merasa lebih mudah dan lebih cepat dalam menghitung dengan metode gasing; (3) peserta pelatihan memberikan respon positif (78\%) terhadap kegiatan pelatihan ini.
\end{abstract}

Published by:

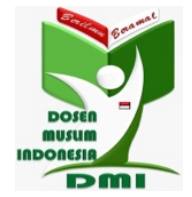

Copyright (C) 2021 The Author(s)

This article is licensed under CC BY 4.0 License (cc) BY 


\section{Pendahuluan}

Peningkatan Sumber Daya Manusia yang berkualitas penting dilakukan agar SDM yang dihasilkan mampu bersaing di segala lini (Rohim \& Sari, 2019). Untuk meningkatkan kualitas SDM dengan memberikan pelatihan-pelatihan, salah satu program pelatihan yang dapat diberikan dalam dunia pendidikan yaitu pelatihan metode-metode pembelajaran matematika. Metode pembelajaran matematika yang akan dilatihkan pada kegiatan ini yaitu metode gasing. Metode gasing adalah suatu metode pembelajaran matematika dengan langkah demi langkah yang membuat anak menguasai matematika secara gampang, asyik dan menyenangkan. Kunci metode gasing ini adalah proses langkah demi langkah, yang disusun sedemikian rupa sehingga penguasaan materi dibangun dari pemahaman materi sebelumnya. Pentingnya proses langkah demi langkah ini dalam metode gasing tercermin sewaktu anak-anak belajar suatu topik, ada titik kritis yang harus mereka lewati. Setelah mencapai titik kritis ini mereka tidak akan sulit lagi mengerjakan soal dalam topik tersebut

Dalam pembelajaran metode gasing ini anak-anak diajak bermain dan bereksplorasi dengan alat peraga sehingga benar-benar terasa dan terbayang konsep yang ingin disampaikan. Jadi yang abstrak selalu diawali dengan sesuatu yang konkrit, sehingga anak-anak dapat jauh lebih mudah mengerti dan mengaplikasikan konsep yang diajarkan. Salah satu ciri khas lain dari metode gasing adalah anak-anak dapat melakukan perhitungan di luar kepala (mencongak) dengan cepat.

Contohnya anak-anak dapat melakukan perkalian 12 x 21 secara mencongak. Anak-anak juga menyelesaikan soal cerita dengan pendekatan logika dan eksplorasi, tanpa perlu menghafal rumus yang terkadang mengaburkan apa yang menjadi esensi suatu permasalahan. Selain itu, pembelajaran matematika gasing disampaikan dengan cara yang menyenangkan, selain bermain dengan alat peraga, anak-anak menyanyikan lagu untuk menghafal perkalian misalnya, atau bermain sebuah "games" berhitung yang seru. Dengan begitu anak-anak terdorong untuk belajar terus menerus tanpa paksaan, ini yang dimaksud dengan asyik dan menyenangkan dalam gasing. Dengan pembelajaran metode gasing yang efektif dan menyenangkan ini, maka anak dapat menyelesaikan seluruh materi matematika SD selama 6 tahun dalam waktu 6 bulan.

Metode gasing ini belum pernah digunakan pada sekolah mitra, sehingga pengabdi berinisiatif untuk melakukan pelatihan metode ini sebagai tambahan metode baru bagi guru-guru untuk mengajarkan berhitung dalam matematika.

Tujuan pengabdian ini adalah agar guru-guru memperoleh pengetahuan tentang metode pembelajaran matematika yaitu metode gasing pada materi penjumlahan, pengurangan, perkalian, dan pembagian. Manfaat kegiatan ini yaitu guru-guru dapat dengan mudah mengajarkan materi penjumlahan, pengurangan, perkalian daan penjumlahan kepada peserta didik sehingga peserta didik juga merasa senang tanpa ada kata matamtika itu sulit.

\section{Metode Pelaksanaan}

Pengabdian berpusat di UPT SPF SDN 124 Batuasang, Desa Singa, Kecamatan Herlang Bulukumba pada tanggal 3 Juni 2021. Kegiatan ini dilakukan secara langsung (tatap muka) dengan memperhatikan protokol kesehatan. Sasaran kegiatan ini adalah guru-guru pada sekolah di gugus 5 wilayah 3 Kecamatan Herlang yaitu SDN 124 
Batuasang, SDN 123 Pataro, SDN 315 Karosi, SDN 286 Mallombong, SDN 257 Ba'do'a, SDN 316 Lassanru dan SDN 119 Karassing. Guru yang mengikuti kegitan ini adalah guru kelas I sampai kelas VI. Penentuan peserta pelatihan dilakukan dengan terlebih dahulu meminta data-data guru kelas pada sekolah yang menjadi mitra dan juga meminta kesedian kepala sekolah untuk memberikan izin kepada guru-guru yang akan mengikuti pelatihan. Selain itu tim pengabdi juga meminta kesedian guru-guru untuk mengikuti kegiatan pelatihan tersebut.

Metode yang digunakan pada kegiatan ini antara lain: (1) Metode observasi, dilakukan dengan melakukan wawancara terhadap guru kelas untuk mengumpulkan data tentang metode yang digunakan dalam mengajarakan matematika terutama pada materi penjumlahan, pengurangan, perkalian dan pembagian, (2) Metode ceramah dan demonstrasi dilakukan pada saat menyajikan materi metode gasing, (3) Metode pemberian angket dilakukan setelah penyampaian materi untuk mengetahui respon peserta pelatihan selama kegiatan pelatihan.

Kegiatan pengabdian yang dilaksanakan terbagi menjadi tiga tahap utama, yaitu tahap persiapan, tahap pelaksanaan dan tahap evaluasi. Kegiatan yang dilakukan pada tahap persiapan antara lain: (a) melakukan survey dan observasi pada lokasi dan sasaran, (b) berkoordinasi dengan kepala sekolah sebagai tempat dilaksanakannya kegiatan pengabdian, (c) Menyusun bahan materi pelatihan. Tahap pelaksanaan dilakukan setelah tahap persiapan selesai. Pada tahap pelaksanaan dilakukan kegiatan pelatihan yaitu dengan memberikan penjelasan tentang cara menjumlahkan, mengurangkan, mengalikan dan membagi dengan metode gasing. Tahap evaluasi dilakukan setelah tahap pelaksanaan.Kegiatan yang dilakukan adalah pemberian angket kepada peserta pelatihan untuk mengetahui atau mengukur respon peserta setelah mengikuti pelatihan. Indikator keberhasilan kegiatan ini adalah apabila 75\% guru memberikan respon positif terhadap kegiatan ini berdasarkan angket yang dibagikan.

\section{Hasil dan Pembahasan}

Pelatihan ini dilaksanakan selama satu hari dengan teknis pelaksanaann adalah pelatihan secara langsung (tatap muka) dengan tetap mematuhi protokol kesehatan. Pelatihan ini mampu memberikan pengetahuan baru tentang metode dalam pembelajaran matematika terutama pada materi penjumalahan, pengurangan, perkalian dan pembagian. Sebelum kegiatan pengabdian dilaksanakan, pengabdi berkoordinasi dengan pihak sekolah mitra atau kepada Kepala Sekolah meminta data-data guru kelas. Pengabdi melakukan observasi terkait tentang metode guru dalam mengajarkan materi dasar matematika yaitu perhitungan dua digit. Observasi ini dilaksanakan dengan cara mewawancarai guru kelas. Selanjutnya pengabdi menyeleksi guru yang akan menjadi peserta dalam pelatihan ini dari 7 sekolah dengan jumlah guru secara keseluruhan yaitu 56 guru. Banyaknya guru mengikuti kegiatan ini yaitu 28 orang guru kelas 1 sampai dengan kelas 4. Dalam rangka persiapan pelatihan, maka hal-hal yang dipersiapkan pengabdi adalah materi pelatihan dan juga angket respon peserta pelatihan terhadap pelaksanaan pelatihan. Tahap pelaksanaan dilakukan setelah seluruh tahap persiapan selesai. Pelaksanaan pelatihan diawali pembukaan oleh kepala sekolah mitra yang menjadi pusat tempat dilaksanakannya kegiatan (Kepala Sekolah UPT SPF SDN 124 Batuasang). Pada tahap ini pengabdi memberikan penjelasan mengenai apa itu metode gasing. 

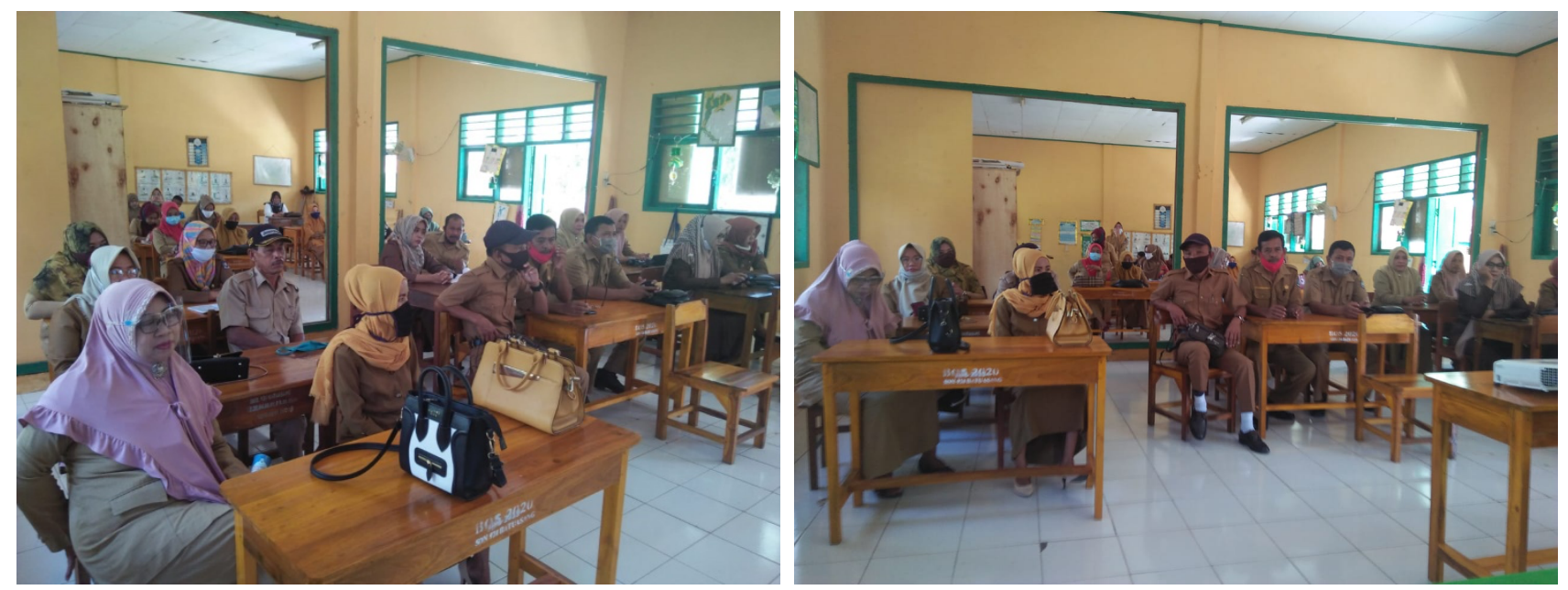

Gambar 1. Peserta Pelatihan Metode Gasing

Sebelum pengabdi menerapkan metode gasing pengabdi terlebih dahulu memberikan pengenalan awal mengenai metode gasing. Selanjutnya pengabdi menjelaskan metode gasing pada materi penjumlahan, pengurangan, perkalian, pembagian.

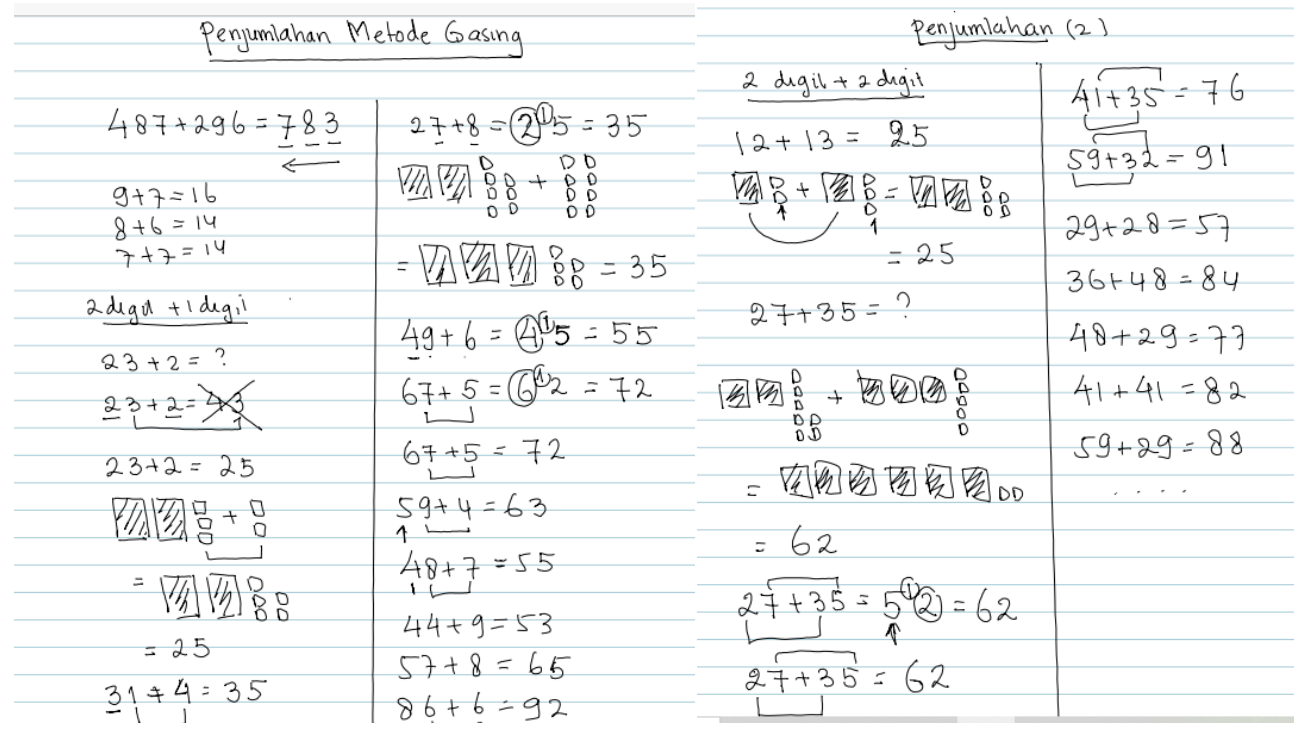

Gambar 2. Penjumlahan dengan Metode Gasing

Gambar 2 menunjukkan materi penjumlahan 2 digit + 1 digit, 2digit dengan 2 digit yang dilatihkan dengan metode gasing yang ditampilkan dalam power point. Tim pengabdi memberikan dua soal untuk sesi interaktif dengan peserta pelatihan untuk mengetahui sejauh mana pemahaman peserta terhadap penjumlahan dengan metode gasing. Selanjutnya tim pengabdi memberikan penjelasan mengenai pengurangan dengan metode gasing. 
Vol. 1. No. 3. November 2021

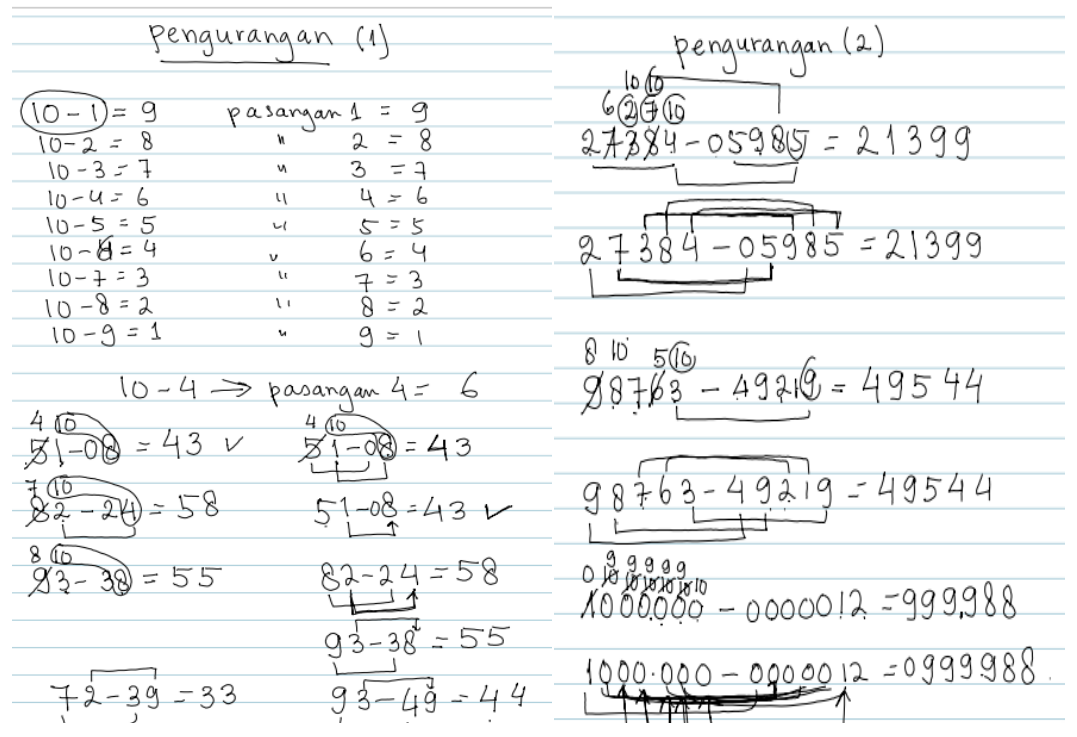

Gambar 3. Pengurangan dengan Metode Gasing

Gambar 3 menunjukkan materi pengurangan 2 digit + 1 digit, 2 digit dengan 2 digit, sampai 5 digit - dengan 5 digit yang dilatihkan dengan metode gasing yang ditampilkan dalam slide power point. Selanjutnya tim pengabdi memberikan penjelasan mengenai perkalian dengan metode gasing seperti pada gambar berikut.

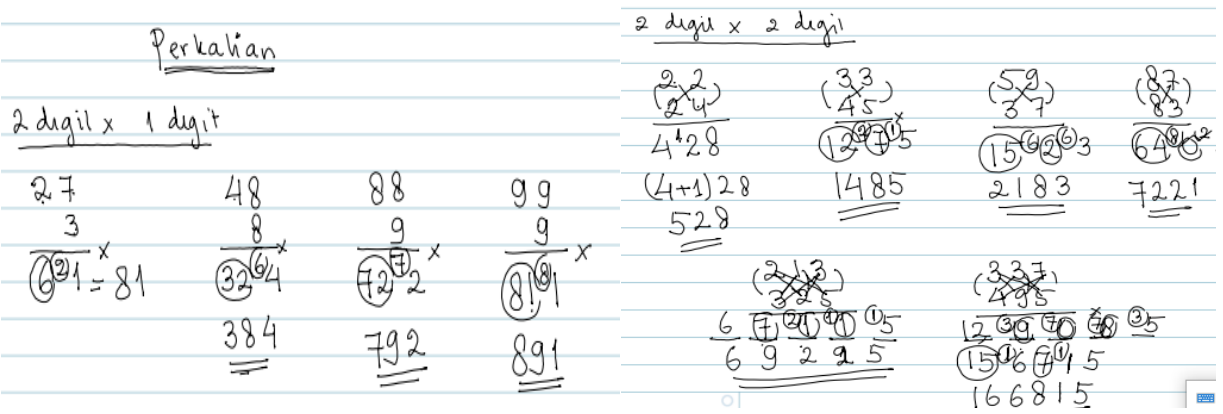

Gambar 4. Perkalian dengan Metode Gasing

Gambar 4 menunjukkan materi perkalian 2 digit +1 digit, 2 digit dengan 2 digit, sampai 3 digit - dengan 3 digit yang dilatihkan dengan metode gasing. Materi terakhir adalah penggunaan metode gasing untuk menentukan pembagian.

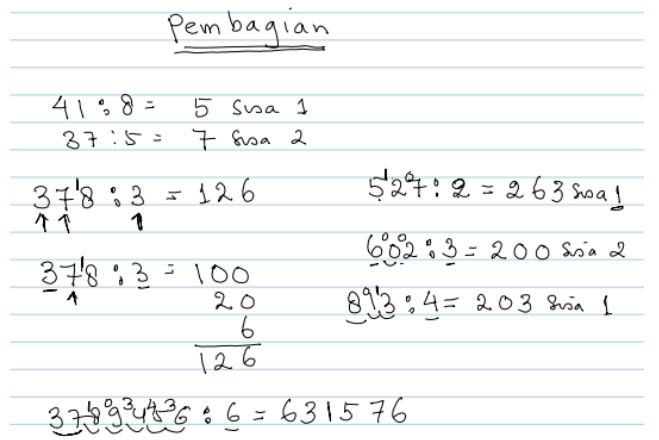

Gambar 5. Pembagian dengan Metode Gasing 
Gambar 5 menunjukkan materi pembagian 2 digit +1 digit, 2digit dengan 2 digit, sampai 5 digit - dengan 5 digit yang dilatihkan dengan metode gasing. Tim pengabdi memberikan satu soal setiap selesai menjelaskan mengenai penerapan metode gasing pada suatu operasi matematika. Hal tersebut pengabdi lakukan untuk mengetahui sejauh mana para guru peserta pelatihan memahami penerapan metode gasing.

Diakhir kegiatan pengabdi membagikan angket respon kepada peserta pelatihan terhadap kegiatan yang telah dilaksanakan. Berikut merupakan hasil angket respon peserta pelatihan (Lihat Tabel 1).

Tabel. 1. Respon peserta pelatihan terhadapan metode gasing

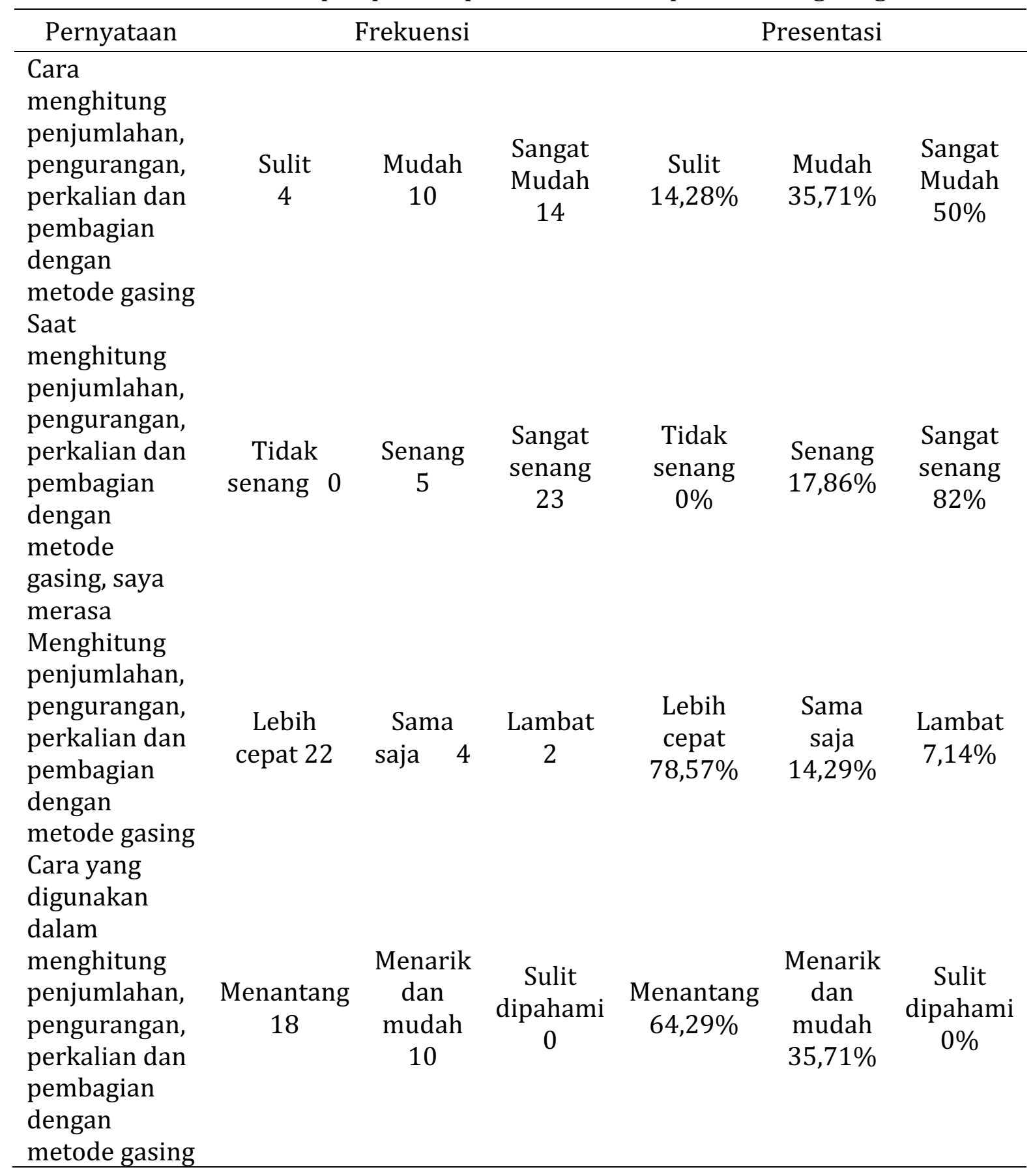


Berdasarkan Tabel 1, terlihat bahwa pada umumnya peserta pelatihan memberikan respon yang positif terhadap pelatihan metode gasing ini. Beberapa peserta didik menganggap bahwa metode gasing merupakan cara yang menantang untuk menentuka perhitungan dalma materi penjumlahan, pengurangan, perkalian dan pembagian. Selain itu 78,57\% peserta pelatihan mengatakan dengan metode gasing lebih cepat dalam melakukan perhitungan.

\section{Kesimpulan}

Kegiatan pelatihan pembelajaran matematika dengan metode gasing untuk guru kelas IV sampai kelas VI yang berpusat pada UPT SPF SDN 124 Batuasang membuat peserta pelatihan antusias mempelajari matematika. Kegiatan ini terlaksana dengan baik dan diikuti sebanyak 28 peserta yaitu guru kelas yang berasal dari 7 sekolah pada gugus 5 Wilayah 3 Kecamatan Herlang Bulukumba. Dari hasil seluruh rangkaian kegiatan ini dapat disimpulkan bahwa: (1) peserta pelatihan memahami metode gasing dengan baik; (2) peserta pelatihan merasa lebih mudah dan lebih cepat dalam menghitung penjumlahan, pengurangan, perkalian dan pembagian dengan metode gasing; (3) peserta pelaihan memberikan respon positif terhadap kegiatan pelatihan ini. Secara umum kegiatan ini memberikan pengetahuan baru kepada peserta pelatihan yaitu guru kelas tentang salah satu metode cepat, asik dan menyenangkan untuk melakukan perhitungan dalam matematika. Berdasarkan hal tersebut tim pengabdi menyarankan kepada guruguru untuk memperkenalkan metode gasing sebagai salah satu alternatif untuk menghitung apalagi untuk anak didik yang baru menginjakkan kaki di sekolah dasar. Untuk kegiatan pengabdian selanjutnya, Tim pengabdi memberikan rekomendasi agar melaksanakan pelatihan metode gasing bagi peserta didik.

\section{Ucapan Terimakasih}

Kegiatan pelatihan ini dapat terlaksana dengan baik berkat adanya dukungan dan kerja sama serta partisipasi dari berbagai pihak. Oleh karena itu tim pengabdi mengucapkan terimakasih kepada SDN 123 Pataro, SDN 315 Karosi, SDN 286 Mallombong, SDN 257 Ba'do'a, SDN 316 Lassanru, SDN 119 Karassing, dan khususnya Kepala Sekolah UPT SPF SDN 124 Batuasang sebagai tempat dilaksanakannya kegitan pengabdian ini, serta seluruh pihak yang membantu dan berpartisipasi dalam kegiatan pelatihan ini.

\section{Referensi}

Aprijon. Pelatihan Matematika Gasing Pada Materi Penjumlahan dan Perkalian Dua Digit Dengan Dua Digit Untuk Siswa kelas VI Sekolah Dasar Negeri Jurnal Menara Riau Vol. 14, No. 01, April, 2020, pp. 45 - 55

Rohim, M. F. \& Sari, A. F. (2019). Keterampilan Siswa Memecahkan Masalah Olimpiade Matematika Ditinjau dari Kepribadian Tipe Senising dan Intuiting. Jurnal Elemen, Vol.5, No.1. 